\title{
The effects of agglomeration on the growth of the Mexican automobile assembly and auto parts subsectors
}

\author{
Los efectos de la aglomeración en el crecimiento de los sectores de \\ automóviles y autopartes en México
}

\section{Jorge Eduardo Mendoza Cota*}

El Colegio de la Frontera Norte, México

Received February 11, 2019; accepted January 20, 2020

Available online October 8, 2020

\begin{abstract}
The paper seeks to estimate the effects of wages, agglomeration and transportation costs on the Mexican automobile assembly and vehicle parts subsectors from 1999 to 2014. The methodology is based on spatial lag and error models. The results indicate that the average wage had a negative effect on the employment of the automobile assembly subsector and that agglomeration initially had a positive impact on that subsector. Transportation costs had a positive effect in the automobile assembly subsector during the two thousand. In the vehicle parts subsector, agglomeration within industry and agglomeration among related industries had positive effects during the early decade of the two thousand.
\end{abstract}

JEL code: L62, C31, R12, O47

Keywords: Agglomeration economies; Automobile industry; NAFTA; Transportation costs; Spatial econometrics

\footnotetext{
${ }^{*}$ Corresponding author.

E-mail address: emendoza@ colef.mx (J.E. Mendoza Cota).

Peer Review under the responsibility of Universidad Nacional Autónoma de México.

http://dx.doi.org/10.22201/fca.24488410e.2021.2458

0186-1042/@2019 Universidad Nacional Autónoma de México, Facultad de Contaduría y Administración. This is an open access article under the CC BY-NC-SA (https://creativecommons.org/licenses/by-nc-sa/4.0/)
} 


\section{Resumen}

El trabajo estima los efectos de los salarios, la aglomeración y costos de transporte en los subsectores de ensamble de autopartes de México en el periodo 1999-2014. La metodología se basa en modelos con rezagos espaciales y en el error. Los resultados indican que el salario afectó negativamente el empleo del subsector de ensamble y que la aglomeración tuvo un efecto inicial positivo en ese subsector. Los costos de transporte también tuvieron un efecto positivo en ese subsector. En el subsector de autopartes, la aglomeración al interior de la industria y la aglomeración entre industrias relacionadas tuvieron un efecto positivo al inicio de la década del dos mil.

Código JEL: L62, C31, R12, O47

Palabras clave: Economías de aglomeración; Industria automotriz; TLCAN; Costos de transporte; Econometría espacial

\section{Introduction}

As a result of the liberalization process that began in the eighties, the Mexican economy has experienced important adjustments in its manufacturing sector. In the first place, the manufacturing growth of Mexico was reoriented towards export promotion and was based on the expansion of the electronics and automobile industries. Also, the Mexican economy experienced a geographic restructuring of its industries based on foreign investment and the opening of export markets abroad (Hanson, 1998).

In addition, with the establishment of the North American Free Trade Agreement (NAFTA) in 1994, a dismantling of the protection systems in Canada, USA and Mexico was undertaken. Tariffs were reduced and eventually removed for passenger cars, and rules of origin specified in the treaty were aimed at setting limits on the percentage of inputs from Non-NAFTA members used to manufacture automobiles and trucks. The share of North American inputs reached 62.5\% in 2002 (Montout and Zitouna, 2004).

During the decades of the eighties and nineties, the Mexican automobile industry experienced an exponential expansion of its exports to the USA. Also, the geographical distribution of assembly plants in the USA and Mexico changed dramatically (Klier and Rubenstein, 2010). A new set of plants were established close to the border or close to the communications networks leading to the "Auto Alley" region in the US (the corridor between the Great Lakes and the Gulf of Mexico). This trend encouraged the agglomeration of automobile plants based on the connection of supplier plants, and also, as in the case of the European 
automobile industry, the existence of highway infrastructure encouraged the localization of auto-parts plants close to assembly plants (Klier and McMillen, 2013). During the nineties, the agglomeration of economic activities became one of the main features of the Mexican manufacturing sector. Mendoza (2002) found evidence that partially corroborates the positive effect of agglomeration economies on Mexican manufacturing growth.

The rapid growth of automobile industry exports has been an important element of the manufacturing export strategy followed by the Mexican economy. The development of the Mexican automobile industry has been based on a re-localization of an important part of the production and assembly plants from the United States (USA) to Mexico, particularly to the central and northern border regions of that country (Mendoza, 2011). As a result, the Mexican automobile industry showed an explosive expansion of production and exports from the decade of the nineties until 2007, when a slowdown of the import demand of automobiles in the USA occurred.

Mexico became an important automobile production center based on the geographical proximity to the exports destination market and labor cost advantages (Debroux and Debrand, 2015). During the 2008 and 2009 recession, the automobile industry of the USA entered into a deep contraction of production and demand that negatively affected the Mexican automobile industry. The severe impact of the economic recession of the US on the Mexican automobile sector suggests the importance of studying the driving forces and the changes within the Mexican automobile industry. Since the automobile industry makes up a significant part of Mexican exports, it is relevant to assess the domestic and external forces driving the pattern of growth of that industry, as well as to measure the initial driving forces in the expansion for that industry. In addition, it is important to analyze the possibility of external economies derived from agglomeration economies (Krugman, 1991). After more than 20 years of the implementation of the North American Free Trade Agreement (NAFTA), the Mexican automobile industry has become geographically concentrated in particular regions. Therefore, this paper estimates the effects of these agglomerations as well as the economic forces that drive the foreign direct investment (FDI) made by automobile multinational corporations, which principally respond to reductions in wages and transportation costs.

The major manufacturing industry that benefited from the dismantling of the Mexican protectionist system and the new rules for FDI established in NAFTA was the automobile industry, which, as a result, increased the production and exports of assembled automobiles and auto-parts to the US market. As mentioned previously, the expansion of the Mexican automobile industry in the last 30 years has resulted from vertical specialization, differences in wages and the geographical proximity to the USA. It has been argued that agglomeration 
forces derived from geographical concentration could encourage further spatial clustering of firms, particularly when conditions exist for firms to be close to their customers (Baldwin, 2013). It is important to address this proposition for the case of the two Mexican automobile industry subsectors, given the different characteristics of their development in terms of output size and final markets.

Within this context, the paper seeks to estimate the existence of agglomeration economies in the automobile assembly and the auto parts subsectors. To fulfill that purpose, the analysis of statistical information from the automobile and the auto-parts sectors is used, according to the Industrial Census of Mexico. To analyze employment growth, agglomeration indexes and a transportation cost proxy were constructed, and subsequently, coefficients of those variables were estimated using spatial and error lag econometric models. The paper is structured as follows: first the introduction; then the second section presents the most important facts about the regional expansion of the automobile industry in Mexico; section three discusses the possible spatial interaction within the automobile industry geographical location; section four presents the theoretical approach based on the concepts of external economies and industry agglomeration; section five describes the econometric model and the variables and data base used; section six discusses the econometric results, and the conclusions are presented in section seven.

\section{Regional development of the automobile industry in Mexico}

The expansion of the automobile industry in Mexico is related to the process of globalization and the standardization of products in the international market. The main force behind the emergence of the Mexican automobile industry as an important exporter was the multinational automobile corporations seeking to reduce costs and generate economies of scale. The Mexican automobile industry was established in the early twentieth century in order to supply the domestic market. However, it wasn't until the period between the seventies and eighties that a strategy to promote exports was established by the Mexican government. In particular, regulations to impose local content restrictions and to allow foreign investment in the auto-parts subsector were established.

With the creation of the North American Free Trade Agreement (NAFTA), the Mexican economy consolidated its model of economic growth based on manufacturing exports (Barragán and Usher, 2009). Under this model, the automobile industry experienced an expansion of production and exports subject to an increasing integration with the US market and production system. Automobile firms from the USA and other countries such as Germany 
and Japan established plants in Mexico to take advantage of low wage costs (Sturgeon and Van Biesebroeck, 2010).

According to data gathered by the World Trade Organization, Mexico exported $1 \%$ of the total automotive products traded in the world in $1995^{1}$. After continued rapid growth, the Mexican share of total exports of automotive products reached 4\% in 2015 (Table 1). The growing importance of the automobile sector in international trade shows not only the importance of automobile exports but also auto-parts exports. In fact, exports of auto-parts have grown faster than exports of assembled automobiles. The annual average rate of growth of automobile exports was $7.3 \%$ between 1995 and 2015, while the auto-parts exports increased at a rate of $9.2 \%$ and exhibited a higher export value (Table 2).

Table 1

Main economies exporting automotive products 1, 1995-2015

\begin{tabular}{|c|c|c|c|c|c|}
\hline & 1995 & 2000 & 2005 & 2010 & 2015 \\
\hline \multicolumn{6}{|l|}{$\%$ of total exports } \\
\hline Germany & $18.7 \%$ & $17.5 \%$ & $18.6 \%$ & $18.6 \%$ & $18.5 \%$ \\
\hline Japan & $17.6 \%$ & $15.3 \%$ & $13.3 \%$ & $13.7 \%$ & $10.2 \%$ \\
\hline USA & $11.4 \%$ & $11.7 \%$ & $9.4 \%$ & $9.1 \%$ & $9.6 \%$ \\
\hline Mexico & $3.1 \%$ & $5.3 \%$ & $3.8 \%$ & $5.1 \%$ & $7.3 \%$ \\
\hline Korea & $2.0 \%$ & $2.6 \%$ & $4.1 \%$ & $5.0 \%$ & $5.3 \%$ \\
\hline Canada & $9.4 \%$ & $10.5 \%$ & $7.3 \%$ & $4.6 \%$ & $4.6 \%$ \\
\hline Spain & $5.2 \%$ & $4.8 \%$ & $4.7 \%$ & $4.1 \%$ & $4.0 \%$ \\
\hline United Kingdom & $4.4 \%$ & $4.4 \%$ & $4.1 \%$ & $3.6 \%$ & $3.9 \%$ \\
\hline \multicolumn{6}{|l|}{$\%$ of total imports } \\
\hline Germany & $9.7 \%$ & $8.1 \%$ & $8.1 \%$ & $7.6 \%$ & $9.2 \%$ \\
\hline Japan & $2.6 \%$ & $1.7 \%$ & $1.4 \%$ & $1.3 \%$ & $1.7 \%$ \\
\hline USA & $23.4 \%$ & $29.4 \%$ & $21.9 \%$ & $17.1 \%$ & $26.3 \%$ \\
\hline Mexico & $1.0 \%$ & $3.5 \%$ & $2.7 \%$ & $2.6 \%$ & $4.0 \%$ \\
\hline Korea & $0.5 \%$ & $0.3 \%$ & $0.4 \%$ & $0.7 \%$ & $1.4 \%$ \\
\hline Canada & $7.3 \%$ & $8.0 \%$ & $6.2 \%$ & $5.4 \%$ & $6.1 \%$ \\
\hline Spain & $3.6 \%$ & $4.5 \%$ & $4.9 \%$ & $2.8 \%$ & $3.7 \%$ \\
\hline United Kingdom & $6.2 \%$ & $6.2 \%$ & $6.4 \%$ & $4.7 \%$ & $6.9 \%$ \\
\hline
\end{tabular}

Source: Own elaboration based on data from the World Trade Organization Statistics, 1. Automotive products: motor cars and other motor vehicles principally designed for the transport of persons (other than public transport type vehicles) including station wagons and racing cars, motor vehicles for the transport of goods and special purpose motor vehicles, road motor vehicles, n.e.s., parts and accessories of motor vehicles and tractors, internal combustion piston engines for vehicles listed above, electrical equipment, n.e.s., for internal combustion engines and vehicles, and parts thereof (SITC groups 781, 782, 783, 784, and subgroups 7132, 7783), andhttps://www.wto.org/english/res_e/statis_e/merch_trade_stat_e.htm

\footnotetext{
${ }^{1}$ The category of automotive products includes both motor cars, parts and accessories, engines and electrical equipment.
} 
Table 2

Evolution of exports of automobiles and auto-parts of the major exporting countries (millions of dollars)

\begin{tabular}{llcccccc}
\hline \multirow{2}{*}{ USA } & & 1995 & 2000 & 2005 & 2010 & 2015 & AARG \\
& Automobile & 16,799 & 16,950 & 30,836 & 38,897 & 54,862 & $5.9 \%$ \\
\multirow{2}{*}{ Canada } & Auto-parts & 58,402 & 85,535 & 95,753 & 74,203 & 95,127 & $2.4 \%$ \\
& Automobile & 25,089 & 34,909 & 37,096 & 36,715 & 44,623 & $2.9 \%$ \\
\multirow{2}{*}{ México } & Auto-parts & 13,700 & 21,939 & 26,321 & 22,508 & 26,442 & $3.3 \%$ \\
& Automobile & 7,521 & 16,492 & 13,404 & 22,956 & 32,662 & $7.3 \%$ \\
\multirow{2}{*}{ Germany } & Auto-parts & 8,404 & 17,678 & 24,461 & 29,788 & 52,426 & $9.2 \%$ \\
& Automobile & 48,602 & 60,608 & 108,663 & 128,649 & 153,121 & $5.7 \%$ \\
\multirow{2}{*}{ Japan } & Auto-parts & 41,684 & 40,466 & 80,972 & 98,095 & 115,092 & $5.1 \%$ \\
& Automobile & 41,674 & 56,813 & 79,577 & 90,204 & 85,997 & $3.6 \%$ \\
\multirow{2}{*}{ Korea } & Auto-parts & 43,274 & 41,767 & 53,873 & 72,971 & 63,816 & $1.9 \%$ \\
& Automobile & 7,241 & 11,894 & 27,255 & 31,779 & 41,752 & $8.8 \%$ \\
& Auto-parts & 3,876 & 4,799 & 14,072 & 31,640 & 40,619 & $11.7 \%$ \\
\hline
\end{tabular}

Source: Own elaboration based on the Broad Economic Categories (BEC) classification, which is linked to the Standard International Trade Classification. AARG= Annual average rate of growth. https://comtrade.un.org/data/

It has been argued that the expansion of automobile assembly has been related to low wages and transportation costs; on the other hand, growth of the auto-parts responds to the value chain strategy of multinational firms. (Sturgeon and Van Biesebroeck, 2010). Particularly after the establishment of NAFTA, investments in the auto-parts industry expanded not only in the border region but also in other regions of the country. Both subsectors are characterized by their high integration with the US market, a small Mexican domestic market and a high export to production ratio.

Another aspect that stands out regarding the expansion of the automobile industry in Mexico is its geographical heterogeneity and the integration of the local suppliers of inputs and the automobile plants in localized regions of Mexico. These geographical differences have had important implications for both the expansion and recessive phases of the Mexican automobile industry (Unger y Chico, 2004). The employment within the subsector of automobile assembly increased from 55,551 workers to 75,023 between 1999 and 2015, experiencing an annual average rate of growth of $2.6 \%$ (Table 3). The bulk of the employment of the automobile subsector at the regional level is mainly concentrated in a few localities. In 2015, around 67\% of the employment of that subsector was located 12 municipios. 
Table 3

Employment in the Mexican automobile subsector at the county regional level, 1999-2004

\begin{tabular}{lccccc}
\hline County ${ }^{1}$ & 1999 & 2004 & 2009 & 2014 & AAGR \\
\hline Total & 50,551 & 44,067 & 50,905 & 75,023 & $2.6 \%$ \\
041 Cuautlancingo & 13,575 & 11,623 & 13,812 & 15,184 & $0.7 \%$ \\
001 Aguascalientes & 2,545 & 3,056 & 3,829 & 7,047 & $6.8 \%$ \\
030 Hermosillo & 2,349 & 1,985 & 4,124 & 5,073 & $5.1 \%$ \\
037 Silao & 3,248 & 3,507 & 3,507 & 4,195 & $1.7 \%$ \\
030 Saltillo & 2,493 & 2,220 & 1,923 & 3,631 & $2.5 \%$ \\
106 Toluca & 3,914 & 3,269 & 3,047 & 3,558 & $-0.6 \%$ \\
027 Ramos Arizpe & 3,017 & 5,456 & 4,075 & 3,257 & $0.5 \%$ \\
101 Tianguistenco & 2,145 & 1,150 & 2,973 & 2,372 & $0.7 \%$ \\
070 El Salto & 368 & 694 & 1,037 & 2,360 & $12.4 \%$ \\
002 Mexicali & 1,483 & 1,246 & 1,092 & 2,147 & $2.5 \%$ \\
121 Cuautitlán Izcalli & 3,392 & 1,417 & 549 & 1,739 & $-4.5 \%$ \\
\hline
\end{tabular}

Source: own elaboration with data from Manufacturing Economic Census of México, 1999, 2004, 2009 and 2014. National Institute of Geography, Statistics and Informatics. 1. County is the closest geographical description of the political demarcation in México known as Municipio.

The municipio of Cuautlancingo (state of Puebla), where Volkswagen is established, had the largest level of employment with 15,184 workers. It is followed by Aguascalientes, Hermosillo, Silao and Saltillo, where Nissan, Ford, GM and Chrysler are located, respectively. It is important to point out that the production of automobiles is concentrated in the Japanese and German companies, followed by the American companies. Therefore, it can be concluded that the Mexican automobile industry has expanded predominantly based on multinational firms taking advantage of the geographical proximity of that economy to the US market.

One of the characteristics of the auto-parts subsector is that it is located close to both the border cities and the automobile assembly plants, as could be expected from the point of view of agglomeration economies. In 2015, the largest concentration of employment was located in Ciudad Juarez with 77,464 workers out of the total of 623,562 workers employed in that subsector. It was followed by Acuña, Matamoros, San Luis Potosi and Ramos Arizpe. Except for the last municipio, none of those localities are situated in the same municipios where the automobile assembly plants are located (Table 4). Therefore, the rapid expansion of employment in the auto-parts subsector seems to be related to both external and domestic demand. 
Table 4

Employment in the Mexican auto-parts subsector at the municipio regional level, 1999-2014

\begin{tabular}{lccccc}
\hline \multicolumn{1}{c}{ County } & $\begin{array}{c}\text { Total } \\
\text { employment }\end{array}$ & $\begin{array}{c}\text { Total } \\
\text { employment }\end{array}$ & $\begin{array}{c}\text { Total } \\
\text { employment }\end{array}$ & $\begin{array}{c}\text { Total } \\
\text { employment }\end{array}$ & AARG \\
\hline Total & 1999 & 2004 & 2009 & 2014 & \\
037 Juárez & 350,501 & 439,112 & 441,179 & 623,562 & $3.8 \%$ \\
002 Acuña & 96,617 & 81,737 & 76,439 & 77,464 & $-1.5 \%$ \\
022 Matamoros & 15,569 & 23,481 & 7,299 & 27,519 & $3.8 \%$ \\
028 San Luis Potosí & 10,889 & 13,656 & 17,452 & 26,380 & $5.9 \%$ \\
027 Ramos Arizpe & 2,965 & 8,583 & 17,238 & 23,052 & $13.7 \%$ \\
006 Apodaca & 3,397 & 5,847 & 13,181 & 22,381 & $12.6 \%$ \\
014 Querétaro & 6,820 & 13,062 & 10,781 & 22,342 & $7.9 \%$ \\
037 Silao & 5,150 & 9,106 & 14,436 & 16,896 & $7.9 \%$ \\
032 Reynosa & 1,336 & 4,779 & 7,187 & 16,045 & $16.6 \%$ \\
030 Saltillo & 11,747 & 14,835 & 13,753 & 15,852 & $2.0 \%$ \\
011 El Marqués & 7,244 & 5,864 & 8,752 & 15,464 & $5.1 \%$ \\
035 Torreón & 1,057 & 4,011 & 7,497 & 12,473 & $16.5 \%$ \\
106 Toluca & 5,864 & 11,403 & 5,867 & 11,720 & $4.6 \%$ \\
041 Cuautlancingo & 6,290 & 5,368 & 8,315 & 10,563 & $3.5 \%$ \\
\hline
\end{tabular}

Source: own elaboration with data from Manufacturing Economic Census of México, 1999, 2004, 2009 and 2014. National Institute of Geography, Statistics and Informatics. 1. County is the closest geographical description of the political demarcation in México known as Municipio. AARG: annual average rate o growth.

The development of supply chains has helped to reduce the costs of intermediate inputs by taking advantage of the geographical proximity to the demand market (USA). As a result, the Mexican automobile industry has developed assembly plants which use intermediate inputs produced abroad and incorporate value-added to re-export those inputs, mainly to the US market (Hanson, 2010). As a consequence, the multinational automobile firms divide up the operations of design, inputs production, assembly and marketing, thus creating "production chains". The implication for the Mexican automobile industry has been the increasing share of vertical and horizontal integration chains, where inputs from other economies (mainly the USA and China) are transformed in Mexican plants and then re-exported to the markets in the USA (Kose, et al, 2004). According to the World Trade Organization, in 2011, the foreign value-added content as a percentage share of the industry's gross product was $50.4 \%$ for motor 
vehicle exports. In terms of the destination of total exports value added, the percentage share in the economy's total exports to the USA was $32.2 \% .^{2}$

\section{Agglomeration, externalities and economic growth}

\section{Theoretical approach}

In order to investigate the characteristics of the Mexican automobile industry, this paper is based on the theoretical approach of external economies. An important concept for the study of externalities and cost reduction for firms located in industries that are regionally concentrated is the economies of agglomeration. Marshall (1980) identified three main reasons for such externalities: pooled labor markets, availability of inputs and technological spillovers. Arrow (1962) and Romer (1986) pointed out that industrial specialization plays an important role in explaining economies of agglomeration, indicating that they allow technological spillovers. It has been pointed out that technological diffusion can also be generated in a regional industry with a competitive market structure.

Richardson (1973) divided agglomeration economies into location economies and urban economies. Location economies are related to external economies resulting from regional specialization, and urban economies are derived from the economic activity within an urban area. Jacobs (1969) underlined that technological diffusion can be developed from the industrial diversity developed within a competitive market structure.

Krugman (1991b) indicated that there are centripetal and centrifugal forces that determine the economies of agglomeration. Centripetal forces are created by the closeness of workers to larger markets to take advantage of economies of scale and the access to consumption. The centrifugal forces are caused by transportation costs or the high cost of land rent as the factors pushing toward regional decentralization. For the case of urban externalities, Henderson (1974) stressed that the growth of urban centers has to do with the mobility of the factors of production. Transportation costs and urban wages are determinant for employment decisions. The growth of cities implies increasing transportation costs that arise from transport congestion and increasing distances between the workers' housing and the manufacturing plants. However, higher wages attract workers to the cities. The urban center equilibrium expansion path is obtained when the costs of city growth are offset by the external economies created by the specialization of production.

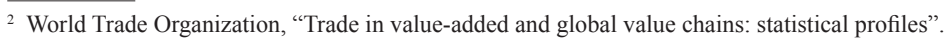


Several empirical papers have been published to estimate the effects of agglomeration economies from the geographical concentration of economic activities. Glaeser et. al (1992) and Glaser (2010) studied metropolitan urban areas in the USA and found that knowledge spillovers are generated by firms located in urban areas. In the case of Mexico, as a result of the changes in the regional manufacturing sector localization during the nineties, resulting from trade liberalization and the establishment of the North American Free Trade agreement (NAFTA), several authors began to study the effect of those changes and the existence of economies of agglomeration in the Mexican economy. Hanson (1994) pointed out that the manufacturing exports strategy followed by Mexico resulted in a relocation of manufacturing activities to the northern border states of Mexico. In addition, Hanson (1996) explained that, in the context of the US-Mexican economic integration, the proximity to labor and input markets has created externalities expressed in agglomeration among related industries. The geographical proximity to the US market encouraged manufacturing agglomeration in the most important cities of the northern border of Mexico (Mendoza, 2002).

\section{Empirical research of agglomeration and the automobile industry}

Agglomeration has been studied in the Japanese automobile industry to estimate the effects of total factor productivity in that industry (Ito, 2004). Using estimates of total factor productivity, the author estimated an Ordinary Least Squares model in order to analyze the transactions between automobile and auto parts producers, for the period 1981-1996. The results indicated a higher productivity in the auto parts subsector than the automobile assembly subsector, with $1.3 \%$ and $0.6 \%$, respectively. In addition, the study found the existence of important agglomeration effects and technological spillover effects.

For the case of the British automobile industry, Boschma and Wenting (2007) studied the spatial evolution of the automobile industry for the period 1895-1968, The authors used a Cox regression and the results indicated that spinoff dynamics are important in the first stages of development, and that localization economies are central for the survival rate of the automobile companies in the first stage of development.

In Italy, Paci and Usai (2004) analyzed the employment dynamics of the manufacturing industries of Italy for the period 1991-2001, focusing on agglomeration economies, firm size, population density and human and social capital. The methodology uses spatial econometric techniques to consider possible cross-border externalities or neighboring effects.

The analysis of agglomeration within the automobile industry indicates that economies of agglomeration have played an important role in the development and permanence of au- 
tomobile companies in different countries. In addition, the agglomeration of suppliers and automobile companies have encouraged productivity and technological spillovers. In the case of the Mexican economy, several papers have addressed the evolution of the automobile industry, but few of them have estimated the possible existence of agglomeration effects.

This paper seeks to estimate the impact of external economies, wages and transportation costs on the automobile assembly and auto-parts subsectors in Mexico. Based upon these theoretical approaches, and the empirical evidence of the performance of the automobile industry in Mexico, the general hypothesis considers that there is a positive effect of economies of agglomeration on the auto-parts subsector employment growth and a lack of impact on the automobile assembly subsector. The specific hypotheses are as follows:

1. The economic integration between Mexico and the US has encouraged the relocation and expansion of automobile manufacturing production, intensifying agglomeration among related industries in the automobile sector in Mexico.

2. Agglomeration within the auto-parts subsector has generated externalities for the automobile industries located near the plants supplying inputs.

3. Transportation costs and the proximity to the markets of the factors of production and final goods has promoted the expansion of the automobile sector.

4. Given the lack of regional concentration of assembly plants, the automobile assembly subsector is not likely to show economies of agglomeration.

In this context, the general goal of the study is to evaluate the impact of the external economies on the employment growth within the automobile and auto-parts subsectors in Mexico.

\section{Empirical model and econometric strategy}

The empirical research of the determinants of the Mexican automobile industry has used different econometric techniques; Mendoza (2011) studied the short and long term effects of the US automobile industry on the automobile and trucks subsector for the period 1994-2008 applying a VAR model. The results corroborated the strong relationship between this industry and the Mexican and US business cycles, both in the short and long term.

Lecuona, and Pavon (2016) studied the effect of the Mexican automobile exports on the economic growth of Mexico and the external and domestic factors that have impacted that manufacturing activity. By applying several OLS models to test the impact of automobile exports on the Mexican economic growth and both external and domestic determinants for the Mexican automobile dynamics, the authors concluded that the economic activity in 
Mexico, the demand from the USA, and the lower Mexican wages have a positive impact on the establishment of automobile plants in Mexico,

Félix, Castro and Aboites (2018) studied the effects of potential tariffs imposed by the USA on Mexican automobile exports. The study uses a VEC time series methodology. The results suggested that higher tariffs would eliminate the advantages of the Mexican economy. A Granger causality test indicated a positive effect of the automobile auto-parts industry on the economic activities. The counterfactual analysis showed a more adverse effect of tariffs on employment in regions where the automobile industry is located.

The regional location of the Mexican automobile industry was analyzed by Carbajal, Almonte and Mejía (2016). They divided the concentration of the automobile industry in four regions and estimated a panel data model. The results suggested that the automobile industry has an important role in the expansion of the Mexican manufacturing sector and GDP.

The analysis of the automobile industry from the perspective of agglomeration economies has not been studied for the Mexican economy. Therefore, the empirical approach that explains the effect of external economies of agglomeration on the Mexican automobile industry is based on Fujita and Thisse (1996) and Lall, Shalizi and Deichmann (2004), they developed a theoretical model of monopolistic competition, assuming symmetric firms and effects of agglomeration due to spillovers in a specific location. The firms that are located close to each other benefit from economies of agglomeration derived from the interaction among firms from the same industry, that are located in a region. Following Glaeser et al. (1992), based on a neoclassical model of growth, a short run Cobb-Douglas profit function which includes externalities can be established as follows:

$$
Y_{r t}=A_{r t} f\left(T_{r t}\right)-S_{r t} T_{r t}-D_{r t}
$$

Where $Y$ is profit, $T$ is labor factor, $s$ is wage, $\mathrm{D}$ is distance and $\mathrm{A}$ is technology. The function also includes transportation costs, given their importance in the localization decision of firms to establish plants closer to the input and output markets.

If the automobile industry is located in a specific location and, as a result, external economies arise, the production function of the output is made up of a component $A_{r t} f\left(T_{r t}\right)$, where $\mathrm{A}_{\mathrm{rt}}$ represents both technology and externalities that increase productivity and, therefore, reduce the costs for the industry at time $t$ in location $r$. Given that statistical information on capital stock is difficult to estimate for the Mexican economy, the model is considered a short run production function and therefore, the estimations do not reflect the total increase in productivity arising from technological advancements and from capital accumulation. 
In order to estimate the impact of agglomeration economies, and based on the above theoretical approach, the empirical model considers the following determinants of regional growth in the automobile industry:

1. Intra-industry external economies derived from the localization of same industry firms;

2. Inter-industry external economies resulting from localization of related industry firms;

3. Transportation costs, which are expressed as a value-added produced by the automobile industries weighted by the distance to the US-Mexican border; and

4. Relative regional wages.

The sources of external economies in the model are given by the effects of agglomeration on manufacturing activities which do not relate to the automobile industry, as well as on related manufacturing activities within the automobile sector, and also by the pecuniary external economies created by the proximity to the market.

Regarding the automobile and truck subsector, the analysis will be focused on the effect of employment agglomeration, transportation costs and wages on the growth of the automobile industry. The methodology consists of estimating a spatial lag model and a spatial error model (Anselin, 1988), for the period 2009-2014. The methodology is based on estimations of the spatial lag and spatial error models using a Maximum Likelihood method (ML) developed by Anselin and Bera (1998).

In order to take into account the spatial effects of neighboring regions on the growth of the Mexican automobile industry, the cross-section regression $Y=\mathrm{XB}+\varepsilon$, where $\mathrm{Y}$ is the rate of growth of the automobile industry and B are the determinants of growth with a classical error term is changed for both a Spatial Autoregressive Model (SAR) and Spatial Error Model (SEM). The SAR model considers that the dependent variable is reliant on the levels of $Y$ in neighboring locations. Therefore, in this paper the average growth rate of the value-added generated in a region is dependent not only on the levels of agglomeration in the region, but also on the agglomeration of neighboring regions.

In order to eliminate the correlation between errors and regressors that can generate biased and inconsistent results, a reduced form is presented:

$$
(I-\rho W) \Delta L N\left(\frac{V A_{i r t}}{V A_{i t}}\right)=(I-\rho W)^{-1} X \beta_{i r t}+(I-\rho W)^{-1}
$$

Where

$\mathrm{W}=$ spatial matrix

$\beta_{\text {irt }}=$ coefficients

$\varepsilon=$ vector of error terms

$\rho=$ spatial autoregressive parameter 
The SEM model provides estimations of the spatial impact through the error term as follows:

$$
\Delta L N\left(\frac{V A_{\text {irt }}}{V A_{i t}}\right)=X \beta_{\text {irt }}+(I-\rho W)^{-1} v
$$

Where:

$$
\varepsilon=(I-\rho W)^{-1} v
$$

The models are based on the Generalized Method of Moments (GMM) estimation. The procedure estimates coefficients, the error autoregressive coefficients and incorporates a spatially weighted regression. The advantage of this methodology consists of the possibility of eliminating the heteroscedasticity generated by the spatial heterogeneity that arises from the geographical location of observations.

The spatial weight matrix included in the estimation is used to consider the spatial relations of the regional units considered in the model. The weights reflect the spatial influence of one location $j$ on another location $i$. The construction of the matrix is based on 0 for units which are not affected by neighboring units and or 1 for units which are influenced by contiguous units.

One of the most important applications of spatial econometric models is related to externalities that are linked to the location of economic activities such as technological innovation and the stock of knowledge, agglomeration economies and pollution derived from industrial activities (LeSage and Pace, 2009). Therefore, external economies arising from the agglomeration of economic activities in a specific location can have important effects on neighboring regions. Those impacts can be estimated by using both spatial lag models, which include spatial lags of the neighboring explanatory variables, combined with a spatial autoregressive structure to generate a spatial extension of a regression model.

Therefore, the spatial regression models use the links between regions and the coefficient estimated to provide information about the explanatory variables of the region and the potential effect on other regions. As a result, the technique is useful for analyzing the interactions of the independent and explanatory variables between regions. In this paper the dependent variable is the rate of growth of the value-added of the automobile assembly and auto parts industries and the explanatory variables are the effect of agglomeration and distance. The estimations are based on a log of the short-term Cobb-Douglas production function, the regression equation that was estimated for the different periods of the two subsectors is the following:

$$
L N\left(\frac{V A_{i, r, t+1}}{V A_{i, t}}\right)=\alpha+\beta_{1} L N\left(A 1_{i r t}\right)+\beta_{2} L N\left(A 2_{i r t}\right)+\beta_{3} L N\left(T C_{i r t}\right)+\beta_{4 L N}\left(W_{i r t}\right)+\varepsilon_{i r t}
$$


The dependent variable is the relative value added in the two subsectors at the municipal level for the three periods considered:

$$
\mathrm{LN}\left(\mathrm{VA}_{\mathrm{i}, \mathrm{r}, \mathrm{t}+1} / \mathrm{VA}_{\mathrm{i}, \mathrm{t}}\right)=\left[\mathrm{LN}\left(\mathrm{VA}_{\mathrm{i}, \mathrm{r}, \mathrm{t+1}}\right)-\mathrm{LN}\left(\mathrm{VA}_{\mathrm{irt}}\right)\right]-\left[\mathrm{LN}\left(\mathrm{VA}_{\mathrm{i}, \mathrm{t}+1}\right)-\operatorname{LN}\left(\mathrm{VA}_{\mathrm{it}}\right)\right]
$$

where

$\mathrm{VA}_{\mathrm{i}, \mathrm{r}, \mathrm{t}+1}=$ is the value-added of subsector $i$ in the region (municipio) $r$ at time $t+1$.

$A 1_{i r t}=\left[\frac{V A_{i r t} / V A_{i t}}{V A_{i t} / V A_{t}}\right]$ is the regional specialization index of the value-added of the two subsectors of the Mexican automobile industry at the municipal level. In this paper it is considered that $\mathrm{A} 1<1$ generates positive external economies in the automobile subsectors mentioned. Therefore, a positive coefficient of that variable would corroborate the existence of positive externalities.

$A 2_{\text {irt }}=\left[\begin{array}{l}V A_{i k t} / V A_{i r t} \\ V A_{k t} / V A_{i t}\end{array}\right]$ is the agglomeration index of related industries, which are those that have the same classification of the North American Industry Classification (NAICS) at the two-digit level. The index works as a proxy to estimate possible effects of the links between suppliers and consumers of inputs in related industries grouped at the four-digit level. The greater the value of the index, the higher the level of specialization of the region.

$\mathrm{K}=$ is the industry classification at the two-digit level.

$$
W=\left[\frac{W_{i r t} / L_{i r t}}{W_{i t} / L_{i t}}\right] \text { is the relative annual wage per worker within the four-digit subsector } i
$$

for the region $r$ during the period $t$, weighted by the annual average wage for the industry at the national level $j$ during the period $t$. It is assumed that a higher average wage will attract workers to the region.

Finally, relative transportation costs are measured with a proxy index based on the distance from the location where the industry is located to the closest border port with the USA, multiplied by the share of the value-added generated in the subsector at the municipal level to the total industry value-added generated in that region. The indicator can help estimate the effect of pecuniary economies based on the proximity to final markets and on the expansion of the automobile subsectors studied. An inverse relationship between the coefficient of this variable and the value-added growth is assumed. Formally, the index is expressed as follows: 


$$
T C_{i r t}=\frac{D_{i}}{\frac{V A_{i r t}}{V A_{r t}}} D_{i}
$$

Where:

$\mathrm{D}=$ distance to the closest border port with the USA

The summary statistics of the variables included in the model showed a higher mean of the levels of agglomeration of related industries in the auto-part subsector, suggesting that this variable could be relevant for explaining the employment growth of that subsector (Table 5). In addition, the agglomeration within the same industry in the automobile subsector was significantly higher, indicating the existence of a regional concentration of automobile plants, although there is a small number of these manufacturing centers. The correlation matrix indicates a positive correlation of the coefficient of agglomeration among related industries and the rate of employment growth. Also, the variable distance, which a proxy of transportation costs, and relative wages presented the expected negative effect on growth (Table 6).

Table 5

Summary statistics

\begin{tabular}{llllll} 
Automobile Subsector & \multicolumn{3}{l}{} \\
\cline { 2 - 6 } & TC & A1 & R & A2 & D \\
\hline Mean & 0.1469 & 12.87 & 7.596 & 0.314 & 3.162 \\
Median & 0.1339 & 6.807 & 5.717 & 0.2172 & 2.999 \\
S.D. & 0.6525 & 14.06 & 6.858 & 0.2104 & 0.9852 \\
Min & -1.812 & 1.011 & 0.614 & 0.1108 & 0.9415 \\
Max & 1.703 & 51.92 & 23.95 & 0.9805 & 5.374 \\
Auto-parts subsector & & & & & \\
Mean & 0.1476 & 1.974 & 1.985 & 5.504 & 6.753 \\
Median & 0.2195 & 1.236 & 1.23 & 0.8296 & 6.401 \\
S.D. & 1.179 & 2.186 & 2.199 & 26.75 & 2.279 \\
Min & -7.006 & 0.002165 & 0.0002657 & 0.011 & 1.753 \\
Max & 4.82 & 9.431 & 8.139 & 283.7 & $1.30 \mathrm{E}+01$ \\
\hline
\end{tabular}

Source: own elaboration. Source: own elaboration. $\mathrm{TC}=$ rate of growth of employment, $\mathrm{R}=$ relative wages, $\mathrm{A} 109 \mathrm{~A}=$ Employment agglomeration within the industry, A209A = Employment, agglomeration among related industries,

DA $=$ Transportation costs 
Table 6

Correlation coefficient matrix

\begin{tabular}{|c|c|c|c|c|c|}
\hline \multicolumn{6}{|c|}{$\begin{array}{l}\text { Automobile subsector } \\
5 \% \text { critical value (two-tailed) }=0.3160 \text { for } n=39\end{array}$} \\
\hline $\mathrm{TC}$ & A1 & $\mathrm{R}$ & $\mathrm{A} 2$ & $\mathrm{D}$ & \\
\hline \multirow[t]{5}{*}{1} & -0.1533 & -0.1498 & 0.4038 & 0.4024 & $\mathrm{TC}$ \\
\hline & 1 & 0.9521 & -0.4097 & -0.6055 & $\mathrm{~A} 1$ \\
\hline & & 1 & -0.4628 & -0.5993 & $\mathrm{R}$ \\
\hline & & & 1 & 0.5024 & A2 \\
\hline & & & & 1 & $\mathrm{D}$ \\
\hline \multicolumn{6}{|c|}{ Auto-parts subsector } \\
\hline \multicolumn{6}{|c|}{$\begin{array}{l}5 \% \text { critical value (two- } \\
\text { tailed) }=0.1603 \text { for } \mathrm{n} \\
=150\end{array}$} \\
\hline $\mathrm{TC}$ & $\mathrm{A} 1$ & $\mathrm{R}$ & A2 & $\mathrm{D}$ & \\
\hline \multirow[t]{5}{*}{1} & -0.0439 & -0.0805 & 0.0489 & 0.0607 & $\mathrm{TC}$ \\
\hline & 1 & 0.8392 & -0.1537 & -0.4079 & A1 \\
\hline & & 1 & -0.1427 & -0.3049 & $\mathrm{R}$ \\
\hline & & & 1 & 0.3266 & A2 \\
\hline & & & & 1 & $\mathrm{D}$ \\
\hline
\end{tabular}

Source: own elaboration. Source: own elaboration. TC = rate of growth of employment, $\mathrm{R}=$ relative wages, $\mathrm{A} 109 \mathrm{~A}=\mathrm{Em}-$ ployment agglomeration within the industry, A209A = Employment, agglomeration among related industries,

$\mathrm{DA}=$ Transportation costs

The agglomeration of economic activities within the automobile and auto-parts subsector $\left(\beta_{1}, \beta_{2}\right)$ could generate positive and negative coefficients, depending on the existence of external economies or due to the agglomeration of economic activities. Both the transportation cost proxy and the average wage paid in both subsectors are assumed to have negative coefficients $\left(\beta_{3}, \beta_{4}\right)$. The analysis of spatial spillovers between regions requires an econometric model where the dependent variable is also explained by agglomeration economies of neighboring regions. The sources for constructing the database were the Economic Census of México for the years 1999, 2004, 2009 and 2014 published by the National Institute of Geography, Statistics and Informatics. 


\section{Results of the spatial econometric analysis}

The methodology of the paper is based on spatial econometric techniques. Initially, a local Moran index was estimated in order to test for spatial autocorrelation. The Moran index takes into consideration the input of regions to the global or local autocorrelation, therefore providing information regarding the concentration of economic activity. Based on local indicators of spatial association, a Moran graph and a test of the null hypothesis of random spatial distribution were constructed, by comparing the localization values of variables of neighboring regions for both the assembly and auto-parts subsectors of the Mexican automobile industry.

The Moran Index was constructed using the value-added rate of growth and the lagged value-added rate of growth of the assembly of the automobiles and trucks subsector for the period 2009-2014. The values of the variables are standardized for all the municipios that share at least one border with the initial region. The estimates showed the relationship of the variable valued in one location with respect to the values in neighboring states.

The estimates of the Moran Index (Table 5) showed that in both the automobile and auto-parts subsectors the index indicates a medium level of clustering. The z-value and the p-value test the null hypothesis of no spatial clustering of the regional values of the variable considered. Since both the p-values for both subsectors for the period 2009-2014 were small, the null hypothesis is rejected. However, for the automobile subsector the p-values are negative, showing a disperse distribution and for the auto-parts subsector they are greater than zero, thus implying the existence of a clustered configuration (Figures 1 and 2).

Table 7

Mexico: Local Moran index for the Automobiles and auto-parts subsectors

\begin{tabular}{lll}
\hline & Automobiles & Auto-parts \\
\hline 2009-2014 & & \\
Moran Index & -0.0236 & 0.677 \\
P-value & 0.01 & 0.005 \\
Z-value & -2.1412 & 5.769 \\
\hline
\end{tabular}

Source: Own elaboration with data from the Economic Census 2009 and 2014, INEGI. 


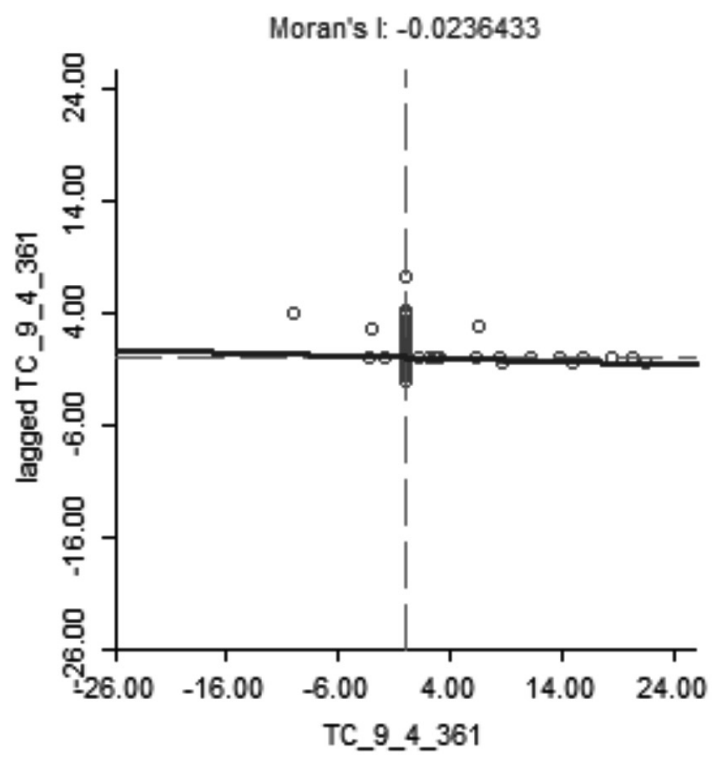

Figure 1. Automobile subsector

Moran's I: 0.0673979

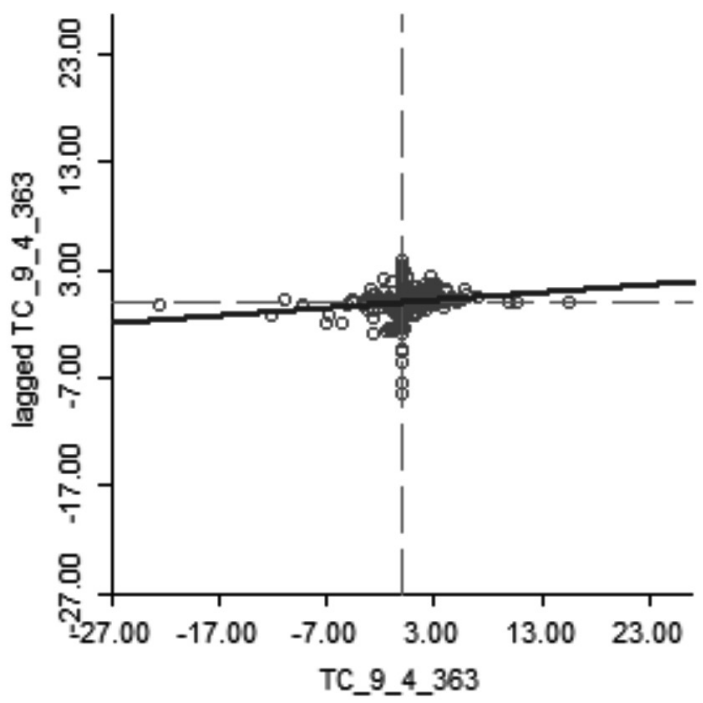

Figure 2. Auto-parts subsector 
In addition, cross section models were estimated for the two subsectors of the automobile industry of Mexico: automobiles and trucks and vehicle parts. The estimations were carried out for the period 2009-2014. With respect to the spatial dependence, the two models improved the goodness of fit, although they exhibited spatial correlation in the lag and error terms, according to the likelihood ratio test.

In order to determine whether the models are well specified, a Breusch-Pagan test was estimated. The results of the test indicate that there was heteroskedasticity in the independent variables in the model. The Likelihood Ratio test for both models indicated that, controlled for spatial dependence, the estimations improved their efficiency. The estimations are based on cross section regression models, with an R squared of $43.1 \%$ for the first model and $9.9 \%$ for the second model.

The spatial lag and error models for the automobile and truck subsector showed the expected negative sign for the coefficient of relative wages and was statistically significant. The coefficients for both the agglomeration within the subsector and the agglomeration among related industries was negative and statistically significant (Table 8). The results did not show evidence of the effect of external economies in the expansion of automobile assembly plants at the geographical level in Mexico. Therefore, for the subsector of automobiles and trucks assembly, there is a possibility that other regional advantages, such as low wages, could be explaining the process of localization. Regarding the effect of transportation costs, the coefficient presented a positive sign in this period. Therefore, transportation costs did not seem to be important for decisions of localization in the automobile and truck assembly subsector.

Table 8

Agglomeration economies and growth in the automobiles and trucks subsectors (2009-2014)

\begin{tabular}{lllllll}
\hline \multicolumn{3}{l}{ Spatial Lag Model } & \multicolumn{3}{l}{ Spatial Error Model } \\
\hline $\begin{array}{l}\text { Dependent } \\
\text { variable: } \\
\text { employment } \\
\text { rate of growth }\end{array}$ & Coefficient & $\begin{array}{l}\text { Standard } \\
\text { error }\end{array}$ & Probability & Coefficient & $\begin{array}{l}\text { Standard } \\
\text { error }\end{array}$ & Probability \\
\hline CONSTANT & 0.001 & 0.001 & 0.649 & 0.000 & 0.001 & 0.991 \\
R09A & -0.006 & 0.003 & 0.039 & -0.005 & 0.003 & 0.080 \\
A109A & -0.002 & 0.006 & 0.193 & -0.003 & 0.002 & 0.091 \\
A209A & 0.008 & 0.0004 & 0 & 0.002 & 0.001 & 0.016 \\
DA & 0.128 & 0.003 & 0.000 & & & \\
Lambda & & & & & &
\end{tabular}




\section{J. E. Mendoza Cota / Contaduría y Administración 66(1), 2021, 1-26}

http://dx.doi.org/10.22201/fca.24488410e.2021.2458

Breusch-

Pagan test

$\begin{array}{lll}\text { DF } & \text { Value } & \text { Probability } \\ 4 & 146184.3 & 0.000\end{array}$

DF

Value

Probability

Diagnostic for spatial dependence

Likelihood

Ratio Test

1

5.693

0.017

1

2.002

0.34

Degrees of

freedom

$\mathrm{C}=$ constant,

R09A=relative wages

$\mathrm{A} 109 \mathrm{~A}=$ Employment agglomeration within the industry

A209A = Employment agglomeration among related industries

DA $=$ Transportation costs

Source: own elaboration.

Concerning the vehicle parts subsector, for both the spatial lag model and the spatial error model, the estimates of the coefficient of the relative wage variable showed a negative sign, which is the expected sign according to the cost minimization objectives of the automobile companies. With respect to the index of agglomeration within the industry, the coefficient was negative, whereas the index of agglomeration among related industries turned out to be positive and statistically significant in the period 2009-2014 (Table 9).

Table 9

Agglomeration economies and growth in the vehicles parts subsector (2009-2014)

\begin{tabular}{|c|c|c|c|c|c|c|}
\hline \multirow[b]{2}{*}{$\begin{array}{l}\text { Dependent variable: } \\
\text { employment rate of }\end{array}$} & \multicolumn{3}{|c|}{ Spatial Lag Model } & \multicolumn{3}{|c|}{ Spatial Error Model } \\
\hline & Coefficient & $\begin{array}{l}\text { Standard } \\
\text { error }\end{array}$ & Probability & Coefficient & $\begin{array}{l}\text { Standard } \\
\text { error }\end{array}$ & Probability \\
\hline \multicolumn{7}{|l|}{ growth } \\
\hline CONSTANT & 0.001 & 0.006 & 0.83 & 0.001 & 0.007 & 0.828 \\
\hline R09P & -0.008 & -0.014 & 0.584 & -0.008 & -0.001 & 0.583 \\
\hline A109P & 0.01 & 0.013 & 0.449 & 0.001 & 0.014 & 0.019 \\
\hline A209P & 0.002 & 0.0006 & 0.001 & -0.002 & 0.001 & 0.002 \\
\hline DP & -0.013 & 0 & 0 & -0.013 & 0.003 & 0 \\
\hline Lambda & & & & 0.001 & 0.052 & 0.988 \\
\hline $\mathrm{R}$ square & 0.099 & & & 0.098 & & \\
\hline \multirow[t]{2}{*}{ Breusch-Pagan test } & DF & Value & Probability & & & \\
\hline & 4 & 12778 & 0 & 4 & 12777 & 0 \\
\hline
\end{tabular}


Diagnostic for spatial dependence

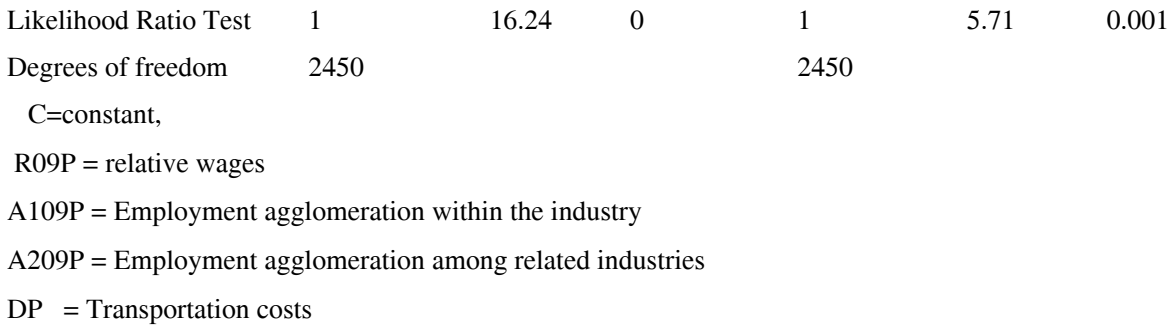

Source: Own elaboration.

The results showed evidence of external economies created by geographical agglomeration in the auto-parts subsector of the automobile industry. Additionally, the coefficient of the proxy for transportation costs did not seem to show a negative sign as expected and, therefore, for that subsector, distance does not have a measurable effect on the expansion of the companies producing auto-parts.

Therefore, the econometric results provided some evidence for supporting the hypothesis of external economies in the auto-parts subsector, particularly during the early decade of the two thousands. This can be explained by the characteristics of the sector in that it consists of a large number of plants that manufacture auto-parts, located both at the border with the USA and in different central regions of Mexico close to the assembly plants. Hence, transportation costs continue to be important, but are not necessarily related to the distance from the Mexico-USA border. They seem to be also related to the distance between auto-parts plants and the automobile assembly plants within Mexico.

\section{Conclusions}

The Mexican automobile industry has experienced rapid and explosive growth in the production of exports destined for the US market. The automobile subsector employment at the regional level is mainly concentrated in a few plants, while the auto-parts subsector is made up by a large number of plants dispersed along the border and central states of Mexico. In addition to its faster annual average rate of growth, the production of auto-parts is characterized by being located both close to the border and to the automobile assembly plants.

The visual examination of the Moran scatterplot indicates the existence of a negative autocorrelation and a clustering of both rapid growth rate and low growth rate regions (municipios) in the automobile assembly subsector. In contrast, the Moran scatterplot for the auto-parts 
subsector showed a positive autocorrelation, suggesting that higher rates of employment in the neighboring regions are clustered in that subsector. The existence of a clustered configuration suggests that this sector could be experiencing agglomeration economies.

The analysis of transportation costs and external economies in the Mexican automobile industry was focused on calculating the effects of agglomeration on the growth of that manufacturing sector. The methodology was based on estimations of the spatial lag and spatial error models using a Maximum Likelihood method. The results of the spatial econometric analysis indicate that for the automobile assembly subsector, wages had a negative effect on employment in that manufacturing activity. One important aspect is that the coefficient for agglomeration within the subsector exhibited a negative and statistically significant coefficient which then changed to positive for both the automobile and auto-parts subsectors during the period 2009-2014. The results suggest that agglomeration economies have not created external economies in the automobile subsector probably because of the lack of the availability of intermediate inputs and high-skilled workers.

The results of the vehicle parts subsector indicate that the index of agglomeration among related industries had positive effects; although the coefficient of the proxy for transportation was negative, both were statistically significant. It can be concluded that the estimations verify the importance of external economies in the auto-parts subsector and that transportation costs have been a decisive factor in the expansion of the automobile assembly subsector. The plausible explanations for these results are related to the geographical characteristics of the Mexican economy, such as the proximity to the USA, and the large number of auto-parts plants located along the border and near the automobile assembly plants in Mexico. Therefore, external economies can be found only in the auto-part subsector which is concentrated both in the northern border region and in the central states where the automobile industry has developed.

These outcomes support previous findings about the positive impact of low wages on the growth of the automobile sector in Mexico (Lecuona and Pavon, 2016). Consistently in several papers, low wages coefficients seem to corroborate the importance of this competitive advantage of the Mexican economy. In addition, this paper corroborates the importance of the regional concentration of employment in the expansion of the automobile industry and the manufacturing sector (Carbajal, Almonte and Mejia, 2016). From this perspective, the present paper provided additional evidence of economies of agglomeration in the auto-parts subsector which supplies both external and domestic demand. Finally, it is important to underline that the results of the study suggest the lack of external economies generated by industry 
agglomeration in the automobile subsector, but supports the idea of external economies in the auto-parts sector which are related to the geographical concentration of related industries where there is interaction between suppliers and automobile plants.

\section{References}

Anselin, L. (1988). Spatial Econometrics: Methods and Models, Kluwer Academic Publishers, Dordrecht, The Netherlands.

Anselin, L. and Anil, B. (1998). Spatial dependence in linear regression models with an introduction to spatial econometrics. En Ullah, Aman, David Giles, (Coords), Handbook of Applied Economic Statistics. (pp. 237289). Marcel Dekker, New York, USA.

Arrow, K. (1962). The Economic Implications of Learning by Doing. The Review of Economic Studies, Stockholm University, Stockholm, Sweden, 29(3), pp. 155-173.

http://dx.doi.org/10.2307/2295952

Baldwin, R. (2013). Global supply chains: why they emerged, why they matter, and where they are going? En

Elms Devorah and Patrick Low (Coords), Global value chains in a changing world, (pp.13-60). Disponible en <https://www.wto.org/english/res_e/booksp_e/aid4tradeglobalvalue13_e.pdf>

Barragán, S. and Usher J. (2009). The role of multinationals in the host country: Spillover effects from the presence of auto car makers in Mexico. Contaduría y Administración, UNAM, Ciudad de Mexico, (228), pp. 83-104. http://dx.doi.org/10.22201/fca.24488410e.2009.652

Boschma R. and Wenting R. (2007). The spatial evolution of the British automobile industry: Does location matter," Industrial and Corporate Change, Oxford University Press, Oxford, United Kingdom, 16(2), pp. 213-238.

$<$ https://doi.org/10.1093/icc/dtm004>

Carbajal Y., Almonte L. and Mejía P. (2016). La manufactura y la industria automotriz en cuatro regiones de México. Un análisis de su dinámica de crecimiento, 1980-2014. Economía: Teoría y Práctica, Nueva Época, 45, 2016, pp. 39-66.

COMTRADE, Standard International Trade Classification, New York, USA. Disponible en https://comtrade.un.org/data/

Debroux, P. y Debrand, J. (2015). The Sustainable Development of Industries: The Case of the Auto Industry, Mexico, Soka University, Aliso Viejo, USA. Disponible en $<$ https://scholar.google.com/scholar?start=70\&q=agglomeration+and+Mexican+automobile\&hl=en\&as_sdt=0,5>

Félix V. G., Castro L. D and Aboites G. M. (2018). Nuevas barreras comerciales de EU a las importaciones automotrices y posibles efectos en el empleo regional. Economía Teoría y Práctica, Nueva Época, 4, pp. 125-176, Disponible en

$<$ http://dx.doi.org/10.24275/ETYPUAM/NE/E042018/>

Fujita, M. and Thisse J. F. (1996). Economics of agglomeration, Journal of the Japanese and International Economies, Elsevier, Amsterdam, Netherlands,10(4), pp. 339-378.

http://dx.doi.org/10.1006/jjie.1996.0021

Glaeser E. et al. (1992). Growth in Cities, Journal of Political Economy, University of Chicago Press, Chicago, USA, 100(6), pp. 1126-1152.

http://dx.doi.org/10.1086/261856

Glaeser, E. (2010). Agglomeration Economics. The University of Chicago Press

Hanson, G. (1994). Regional Adjustment to Trade Liberalization, NBER, Working Paper, Núm. 4713.

Hanson, G. (1998). North American Economic Integration and Industry Location, National Bureau of Economic Research (NBER), Working Paper, (6587). Disponible en <http://www.nber.org/papers/w6587> 
Hanson, G. (2010). Why isn't Mexico Rich? National Bureau of Economic Research (NBER), Working Paper, Núm.16470. Disponible en <http://www.nber.org/papers/w16470>

INEGI, Manufacturing Economic Census of México, 1999, 2004, 2009 and 2014, Ciudad de Mexico, Mexico. Disponible en <http://www.beta.inegi.org.mx/proyectos/ce/2014/>

Ito, K. (2004). Plant productivity, Keiretsu and agglomeration in the Japanese automobile industry: An empirical analysis based on micro-data of Census manufactures 1981-1996”, Institute of Economic Research, Hitotsubasi University Research Unit for Statistical Analysis in Social Sciences, Discussion Paper, 51, Tokyo, Japan.

Jacobs, J. (1969). The economy of cities, Random House, New York, USA.

Klier, T. and McMillen D. (2008). Evolving agglomeration in the US auto supplier industry, Journal of Regional Science, Wiley, Hoboken, USA, 48(1), pp. 245-267.

https://doi.org/10.1111/j.1467-9787.2008.00549.x

Klier, T. and Rubenstein J. (2010). The changing geography of North American motor vehicle production", Cambridge Journal of Regions, Economy and Society, University of Oxford, Oxford, United Kingdom, 3(3), pp. 335-347.

http://dx.doi.org/10.1093/cjres/rsq024

Klier, T. and McMillen, D. (2013). Agglomeration in the European automobile supplier industry, Working Paper, Federal Reserve Bank of Chicago, Chicago, USA, No. 2013-15. Disponible en <https://www.econstor.eu/ bitstream/10419/96643/1/77386850X.pdf >

Kose, A., Towe, C. and Meredith G. (2004). How has NAFTA affected the Mexican economy? Review and evidence, International Monetary Fund, Washington D.C., USA, 4(59), pp. 1-49.

Krugman, P. (1991). History and industry location: the case of the manufacturing belt, The American Economic Review, Pittsburg, USA, 81(2), pp.80-83.

Krugman, P. (1991b). Geography and Trade. MIT Press

Krugman, P. (1995). Development, Geography and Economic Theory, The MIT Press, Cambridge, MA, USA.

Lall, S., Shalizi Z. and Deichmann U. (2004). Agglomeration economies and productivity in Indian industry, Journal of Development Economics, 73(2), pp. 643-673.

http://dx.doi.org/10.1016/j.jdeveco.2003.04.006

Lecuona, J. R. and Pavon L. I. (2016). Actividad Económica e Industria Automotriz: la experiencia mexicana en el TLCAN. Instituto Universitario de Investigación en Estudios Latinoamericanos, Universidad de Alcalá Documentos de Trabajo IELAT, Versión Digital, ISSN: 1989-8819, № 89.

Lesage, J. and Pace, K. (2009). Introduction to spatial econometrics, Taylor and Francis Group, Boca Raton Florida, USA.

Marshall, A. (1890). Principles of political economy, Macmillan, New York, USA.

Mendoza, E. (2002). Specialization, Agglomeration and Urban Manufacturing Growth in the Northern Border Cities of Mexico, Journal of Borderlands Studies, University of Victoria, Victoria, Canada,16(2): pp. 71-97.

https://doi.org/10.1080/08865655.2001.9695575

Mendoza, E. (2011). The Impact of the US Automobile Crisis on Mexico's Car and Truck Subsector. Economía Mexicana NUEVA ÉPOCA, 20(2), 281-309.

Mendoza, E. (2011). La crisis de la industria automotriz en México en el marco de la integración económico con los Estados Unidos, ECONOMIAunam, UNAM, Mexico City, Mexico, 8(22): 55-73.

Montout, S. and Zitouna H. (2004). North-south integration and multinationals: the case of the automobile industry in Mexico. En Jean-Louis Mucchielli and Thierry Mayer (Coords), Edward Multinational Firms' Location and the New Economic Geography (p.76) Elgar Publishing, Cheltenham and Camberley, United Kingdom.

Paci, R. and Usai, S. (2008). Agglomeration economies, spatial dependence and local industry growth, Revue D'Economie Industrielle, Brussels, Belgic, No. 123, pp. 87-109. Disponible en <https://journals.openedition. org/rei/3917>

Sturgeon, T. and Biesebroeck J. (2010). Effects of the Crisis on the Automotive Industry in Developing Countries 
A Global Value Chain Perspective, Policy Research Working Paper 5330, The World Bank, Washington, D.C., USA. Disponible en

<http://sds.ukzn.ac.za/files/Sturgeon_GVCs,\%20Crisis,\%20Development\%20in\%20the\%20Automotive\%20 Industry\%20WP.PDF>

Richardson, H. W. (1973). Regional growth theory, (MacMillan, London.

Romer, P. (1986). Increasing Returns and Long-Run Growth, The Journal of Political Economy, University of Chicago, Chicago, USA, 94(5), pp. 1002-1037.

Unger, K. and Chico, R. (2004). La industria automotriz en tres regiones de México. Un análisis de clusters, $E l$ Trimestre Económico, Fondo de Cultura Económica, Mexico City, Mexico, XXI(284): pp. 909-941.

World Trade Organization, Trade in value-added and global value chains: statistical profiles, Geneva, Switzerland.

Disponible en <https://www.wto.org/english/res_e/statis_e/miwi_e/countryprofiles_e.htm>

World Trade Organization Statistics, Automotive products, SITC groups 781, 782, 783, 784, and subgroups 7132,

7783, Geneva, Switzerland, Disponible en https://www.wto.org/english/res_e/statis_e/merch_trade_stat_e.htm 